\title{
Confessionalism and conversion in the Reformation
}

Book or Report Section

Accepted Version

Morrissey, M. (2015) Confessionalism and conversion in the Reformation. In: Simpson, J. (ed.) Oxford Handbooks Online. Oxford University Press. doi: https://doi.org/10.1093/oxfordhb/9780199935338.013.73 Available at http://centaur.reading.ac.uk/40746/

It is advisable to refer to the publisher's version if you intend to cite from the work. See Guidance on citing.

To link to this article DOI: http://dx.doi.org/10.1093/oxfordhb/9780199935338.013.73

Publisher: Oxford University Press

All outputs in CentAUR are protected by Intellectual Property Rights law, including copyright law. Copyright and IPR is retained by the creators or other copyright holders. Terms and conditions for use of this material are defined in the End User Agreement. 


\section{www.reading.ac.uk/centaur}

\section{CentAUR}

Central Archive at the University of Reading

Reading's research outputs online 


\section{Confessionalism and Conversion}

Mary Morrissey

Abstract: Recent research on the Reformation has been concerned with the process by which lay people acquired a religious identity, whether it began merely as an act of political obedience or by a sudden 'conversion' to new doctrines. Confessional politics made it imperative for rulers to try to control the religious allegiances of their people, but the doctrine of conversion (as a spiritual change) made this theoretically impossible. Instead, a 'culture of persuasion' developed by which clerical and secular rulers sought to persuade their people to accept teachings authorized by the state. The possibility of religious dissent, of converting away from the state-sanctioned denomination, made conversion an issue whose importance was far greater than the actual number of converts. The study of confessionalism and conversion emphasises two theses fundamental to Reformation studies: that the era produced radical changes in the ways that people thought about their personal and communal identities, and that it made individuals' religious choices the urgent concern of their governors.

Keywords: confessionalization, conversion, conformity, identity, polemic, persuasion.

Confessionalism and conversion are misleadingly straightforward terms. At first glance, they seem to refer simply to the 'outward-facing' and the 'inward-facing' sides of a change of religion; confessionalism is the outward adaptation of a public religious identity (The Oxford English Dictionary offers 'the principle of formulating a Confession of Faith; adherence to a formulated theological system'1); conversion is the inward 'change of heart' that finds expression in that outward change. This dichotomy fails to capture the significance of these terms to the current historiography of the Reformation, however, and it is possible to argue 
that much of the most vital work in Reformation studies is concerned with the questions of identity that coalesce around notions of confessionalism, conversion and conformity.

For much of the last thirty years, the article to which undergraduates studying the English Reformation were first sent was Christopher Haigh's 'The Recent Historiography of the English Reformation' (1982), where four models of how the Reformation happened were offered: rapid from above (i.e., successful conversion of the people to Protestantism came about because of the actions of government, gentry and senior ecclesiasts); rapid from below (success was due to the adaptation of new doctrines by members of the labouring and mercantile classes); slow from above; and slow from below. The last two were clearly the forerunners in 1982, and their lead would lengthen in the years to follow (not least because of the influence of Haigh's own work). ${ }^{2}$

Haigh's essay is exemplary for its methodological clarity, but it sketches out a field of research that did not give much attention to the mechanisms used to effect changes in religious allegiances and beliefs. Nor did the historical works that Haigh summarises give very detailed consideration to what it means to say that an individual or a community changed from one set of Christian beliefs to another, not wholly different, set of beliefs. That question has been the focus of much recent research, particularly on the question of conversion. But conversion is a term whose history in Western thought is hard to accommodate to the large-scale political re-orientation that a change in a national Church involves. Conversion means 'to turn', and through its Greek form (metanoia, a turning of the mind) is closely associated with the notion of penance: its use in the Gospels was often translated as 'repent'. ${ }^{3}$ Conversion was a turning away from a certain kind of life and towards 
a more serious attitude to religion, assisted or prompted by divine grace. Before the Reformation, the term was usually used of those who took monastic vows: they were 'converted' to a religious life. In the later seventeenth century, it became associated with the conversion narratives told by members of 'gathered' churches (self-selecting congregations who required an account of an individual's experience of justification, of God enabling this change of heart, from all those seeking full church membership). ${ }^{4}$ The notion of a conscious choice to live up to religious dogma need not necessarily involve a change of religious affiliation; that happened when the process of converting to religion prompted doubts about one's own church as the truest teacher of doctrine. As Michael Questier explains:

In Judaeo-Christian thought, conversion comprises both an inward and an outward alteration. Inward renewal under the influence of grace requires the setting aside of former standards of behaviour and sometimes the adoption of different standards of religious belief and activity. ... While an individual's 'conversion' can mean anything from an explosive evangelical sensation to a quiet, cold intellectual modification of ideas, it frequently includes both. Conversion, then, refers first to the efficacious moment in the process generally described as justification. Though the word itself signifies merely a turning, in Christian theology it indicates initially the point at which man enters into a new relationship with Christ through the action of the Holy Spirit (mediated through the Church) and then subsequently embarks on a pilgrimage of grace. ${ }^{5}$

It is hard to claim that England became Protestant through the cumulative effect of individual conversions of this sort. The numbers of people who might be considered convinced Protestants by the reign of Edward VI was small, even if there was a larger 
number of people whose religious beliefs were not quite what they had been in the 1520 s. Alec Ryrie has argued that, whatever the problems of attempting quantitative analysis of changes of religion in the mid-Tudor period, one thing is clear: 'religious change under Henry VIII and Edward VI cannot be understood simply as a process of changing Catholics into Protestants.' 6

The first problem is one of definition: what does it mean to 'be' a Roman Catholic, particularly in the years before the Council of Trent, or to 'be' an English Protestant in the years before the Elizabethan settlement? Given that many people in early modern England received only (and perhaps not even) rudimentary catechising, what does it mean to say that they ceased to be one kind of Christian and became another? Did they consciously decide that certain fundamental doctrines were misunderstood by one set of clergymen, and that they must therefore seek out instruction from another set of clergymen whom they knew taught differently? Apart from anything else, that raises the question of how sets of clergy could be identified in the period before neat doctrinal statements marked out the divisions between theologians. Or did people change allegiances before ideas: did they decide that their obligation to those in authority meant that they should follow any changes in religious devotions that were instituted? Some individuals must have found themselves reliving that process more than once in an adult life that spanned 1530 to 1560 . Obedience was a positive virtue for most people in our period, and Ethan Shagan has argued that the Henrician government made use of this fact. It was, he says, 'the peculiar genius of Henry VIII and his advisors' to 'politicise their Reformation, keeping any questions of its legitimacy focused on loyalty rather than theology', and 'defining opposition to the royal supremacy as treason 'papistry' rather than Catholicism'. ${ }^{7}$ Religious conservatives found themselves within the scope of the treason laws if they objected to the break with Rome, and many clergymen 
(including reform-minded 'Henrician Catholics' like Stephen Gardiner) found themselves on the wrong side of the argument once doctrinal changes were implemented thereafter.

Religious belief and religious allegiances were not co-extensive, but neither were they separable. For many ordinary believers, the Reformation was at first a matter of obedience, not of conversion. Conformity seems a more likely model for thinking about how many of the intellectually uncommitted responded to the doctrinal changes of the mid-Tudor period. One of the effects of the 'revisionist' historiography instigated by Haigh and Eamon Duffy has been to push back the date at which we can declare the English Reformation 'a howling success in achieving its aim of making England a Protestant country' to sometime in the 1570 s,.Before that date most people were attending church but only a minority were committed Protestants. ${ }^{8}$ By a mix of conformity by some and conversion by others, English people learned to think of themselves, individually and collectively, as Protestant. And the word that best describes that process is confessionalization.

Confessionalization is a term used to describe the closer integration of Church and state identifiable in many German countries in the early modern period. The state supported a single Church's claim to teach and preach in that region, a monopoly on orthodoxy defined through written confessions of faith; the Church's teachings supported the state's claims to obedience, and both forces co-operated in implemented mechanisms for social discipline. ${ }^{9}$ The applicability of this term to the English Reformation has been denied by many historians: the Thirty-Nine Articles do not constitute a full-blown confession of faith, and Tudor governments failed to operate a principle of cuius regio, eius religio; Elizabeth's government learned to cope with minority religious groups instead. Even the debate about religion and the control of social behaviour, which has found a place in English historiography, does not quite fit the model: if anyone, it is the puritans, those 'conditional' members of the English church, who have been seen as the agents of an increased monitoring of the behaviour of the poor, not 
the conformist clergy (even if few of the former went as far as Robert Herrick in applauding 'cleanly wantonness'). ${ }^{10}$ Peter Marshall has suggested, however, that 'the case has not been argued out'. ${ }^{11}$ In his book on Religious Identities in Henry VIII's England, he suggests that one reason why English historians have not used confessionalization as an interpretative tool is a problem with chronology: several of Henry VIII's policies 'would seem to fit the description here', but they happen before 'the great period of confessional doctrinal definition' was getting under way: before the publication of the canons of the Council of Trent, the Helvetic Confession of 1566 or the Lutheran 1580 Book of Concord. ${ }^{12}$

If chronology has been the issue, then German historians have also argued about when the various phases of confessionalization can be said to begin and end. If the neatness of a state-sponsored confessionalization does not match the less concerted efforts of the Tudor governments, then we should remember that the model of 'confessionalization from above' by state forces has been answered by European scholars claiming that 'confessionalization from below' is no less important: self-regulation at a local level can explain social discipline when state forces are not obviously intervening. In places where state power was divided or weak (the United Provinces or Ireland), a process of confessionalization nonetheless took place 'from below'. ${ }^{13}$ Even if viewed as a 'top down' process, the state's sponsorship of a single Church made it incumbent on ordinary people to make a conscious choice to accept or reject those clerics' authority to teach and administer the sacraments. In so doing, they acknowledged the doctrinal and pastoral responsibility of the clergy and accepted a confessional identity, a label identifying them as Protestant or Catholic, even if the full details of the doctrinal disputes around which those labels were constructed remained hazy. Marshall argues persuasively that a process for which confessionalization is the only available word was happening in England in the later years of Henry's reign. And it is one in which English 
people worked through the implications of competing Christian churches and created for themselves this new thing: a religious identity. To quote Marshall again:

It is often suggested that the frequent shifts and turns of government religious policy in the sixteenth century must have confused and disoriented people, leaving them with little clear sense of whether they were supposed to be Protestant, Catholics, or some other type of Christian. Yet I think the possibility that it had precisely the opposite result needs to be investigated seriously - that the orders to remove or restore altars, images, and books had a profoundly catechizing effect, encouraging people to think about their meanings more intensely than they had done before. And as communities divided, the presence of "others" - heretics or papists - invariably sharpened in a dialectical way a self-awareness of religious belonging. Martyrdom, and stories of martyrs, had the same effect. I think we have probably heard too much about compliance, conformity, and passivity as the keynotes of English religion in the Reformation era. $^{14}$

Even before formal divisions between denominations became established, laypeople had to find ways of understanding a radically new situation in which those authorised to determine religious truth were, sometimes literally, at each other's throats. The Massacre of St. Bartholomew's day in August 1572 marked a turning point, according to Diarmaid MacCulloch: before this, the 'largescale slaughter' of the early sixteenth century was mainly 'the consequence of official violence: persecution of heretics, repression of rebellion'. By the 1570 s, 'ordinary people were beginning to own the religious labels that the officially agreed confessions and the decisions of Councils were creating: they found that they were Protestant, 
Catholic, Lutheran, Reformed. They were proud of these identities, and they often grew to hate people of different religious opinions."

Confessionalization was a political process, but it was one that made a religious identity a possibility for ordinary individuals; even if the decision was to conform or not to conform, there was now a decision to be made. This was the only aspect of most people's public persona that they chose; it was not necessarily a function of the family, or place, or the social rank that they were born into, but it was their response to their teachers and the promptings of the Holy Spirit. And that decision was of first importance to the governing bodies responsible for running the Church and the state. Powers to punish were extensive, including the fearful death by burning for those found guilty of heresy (mostly antiTrinitarian ideas after 1558). Less drastic measures were used on those whose errors were considered not fundamental: they could be fined for refusing to attend services in the parish churches, or imprisoned for promoting or aiding those who promoted heterodox beliefs, or for refused to take oaths testifying to their assent to state-sanctioned orthodoxies. Clergymen could be suspended from their livings if they refused to subscribe to acceptance of the Thirtynine Articles and the Book of Common Prayer liturgy. ${ }^{16}$ Nonetheless, the state could not change people's minds, and so the enforcement of religious orthodoxy was not something they could ever expect to control fully. The power to convert belonged neither to the Church hierarchy nor the state: it was the work of the Holy Spirit. The ministers whose function it was to teach and convince, and the government forces with whom they worked, accepted this as part of the doctrine of grace within which their own religious lives were formed. The state concentrated on managing recusancy and dissent when necessary, but co-operated thoroughly with the ecclesiastical authorities for a more ambitious programme of proselytizing at moments (during the Jesuit mission in the 1580s, for example) when the political situation made religious divisions particularly dangerous. Michael Questier has argued that 'different 
political and religious ideas about change of religion gave an immediacy to each other', but that they did not 'fuse', remaining rather 'in a constant tension', with neither subordinate to the other:

Contemporaries could not easily imagine conversion in just the political or the ecclesiastical or the intellectual or the evangelical sense. It is certainly a misreading to visualise opposing clerical groups, through their proselytising, trying to create parties of people who could be defined as either 'Catholic' or 'Protestant' merely on a political basis. Not that politics was not seen as important for the progress of religion. ... Secular politicians might well find clerics useful as propagandists, especially when religion was a matter of extreme political concern (because people defined their political loyalties partly by their religious beliefs). But the people who proselytised with the greatest enthusiasm, the ones for whom an intense concept of conversion was really important, regarded themselves not primarily as agents (or enemies) of the State, or its established Church, but as emissaries of grace, whatever their particular doctrinal beliefs about how grace worked. ${ }^{17}$

Conversion might happen in time to those who were exposed to persuasive teaching, and the co-operation of ecclesiastical and secular forces was concentrated on these efforts. There was a need to link the public and political organising of religion in early modern Europe with the 'change of heart' in individuals that conversion implies. This created a 'culture of persuasion', a term coined by Andrew Pettegree to describe the proliferation of new genres in print, preaching, and the visual arts designed to persuade those who were uncommitted or heterodox to consciously, and conscientiously, adopt the beliefs authorised by their Church and state. Government sponsorship of publications and sermons could be 
effective, and evidence for campaigns of Protestant evangelizing in Edward VI's reign can be found. ${ }^{18}$ Such a 'culture of persuasion' could act as the bridge between the individual conscience that needed to be convinced and the community within which religion was practiced when it coalesced with current practices (in preaching, the visual arts or theatre) because:

Religious choice may still be personal - as it often was - without being private. Decisions were often arrived at in a communal context. Much of the culture of persuasion in the sixteenth century was based on an assumption that decisions would be arrived at collectively. If the Reformation were to succeed, the culture of persuasion would have to work with the grain of this society. Reformers recognized a necessary double process of engagement: with the individual Christian, and with a collective religious consciousness that also had to be nurtured and reinforced. ${ }^{19}$

A 'public sphere', not Habermas' but one that includes a role for the governed as well as governors in early modern politics, has been mapped out successfully in the work of Steven Pincus and Peter Lake, and its growth was a function of the confessional nature of European politics after the Reformation. ${ }^{20}$ The governors' ambition was that those they ruled conform to their orders, and this included the practice of religion. The workings of this public sphere cannot be modelled in a simple hierarchy by which information passed from the learned to the rest by means authorised by government, because the practice of religion made subjects also answerable to God: the government had to convince their people that God was on their side. The Reformation made necessary the creation of modes of persuasion and means of conversion that would connect the institutions that administered religious teaching with the individuals for whom they were responsible. ${ }^{21}$ It made a choice of religions possible, and 
necessary, and the growth of confessional states made the nature of that choice the government's urgent concern.

The literature of confessionalization is inextricably part of this process, not just a representation of it. The divisions between religious denominations were not merely reflected in polemical texts; they were created by them. The polemical literature of sixteenth and seventeenth-century England is extraordinary: clever, and often cruel, it can be witty and blunt and uncompromising. There was no possibility of compromise: if one's opponents were teaching errors, then no right-thinking Christian could amend orthodox views in order to accommodate those errors. The refractory nature of both sides of the Protestant/Catholic confessional divide has been explored by James Simpson, who reminds us that even from an early date there was little possibility of peaceful coexistence. Quoting a letter by Sir Thomas More to Martin van Dorp of 1515, in which More compares contested in a religious dispute to two men 'fighting naked between heaps of stones; neither one lacks the means to strike out; neither one has the means to defend himself', Simpson remarks:

More approaches the fight with a practiced lawyer's viewpoint: he knows that the choice of argumentative weapon must be made with an eye to one's opponent's own arsenal. For all his acuity, however, the actual position points away from intellectual acuity and towards repression by force, since More recognized that, between warring faith groups, the ground of argument is forever without purchase. ${ }^{22}$ 
If victory was impossible, then what was the purpose of polemical literature?

Certainly from the second half of the sixteenth-century, I believe the rhetorical purpose of much polemical religious literature was not to change minds, but to galvanize those who had already 'owned' a confessional label but whose allegiance was shallow, or conditional. I have adapted the term used in preaching rhetoric to describe this kind of polemical literature, whose purpose was to create clear boundaries between religious identities and which used argument to assure the laity that they have plumbed for the true side. ${ }^{23}$ 'Confutational' sermons are designed to counter heretical ideas through argument, but usually in public sermons of the Reformation they were addressed not to those who held the heretical ideas but to those who were being warned against them. And a style of argument evolved that matched this purpose: arguments that could be seen to be won convincingly without the need to explain doctrinal cruces were prized. Among the styles of argument that worked particularly well in this respect were personal attacks on the reliability of the other side as teachers and Christians.

The prime examples of this kind of confessional literature in English are the texts produced in the 'Challenge' controversy, possibly the largest and longest of the polemical battles of the period. It began with a sermon by John Jewel at Paul's Cross on 26 November 1559 , whose ostensible purpose was to convince those who had only reluctantly abandoned the Catholic Mass that they were wise to do so because the historical evidence for the liturgy's orthodoxy was illusory. Jewel therefore 'challenged' Catholic clerics to produce Patristic sources for a series of carefully formulated doctrines and practices (all post-dating 600 , as Jewel knew). ${ }^{24} \mathrm{He}$ concludes that the Catholic clergy are unreliable guides for the laity: they told them the Mass was an apostolic institution, and yet they can produce no Patristic evidence for many elements in the liturgy. Throughout the sermon there is an emphatic appeal to the judgement of the hearers: they are urged to compare the Mass with the 
Bible, and Catholic claims with the writings of the Fathers. So Jewel establishes the lay hearers of his sermon as the judges between two sets of teachers, not two sets of doctrines.

When the challenge was answered, the ground quickly shifted to the correct interpretation of Patristic sources, and the authors struggled to make these more demanding arguments intelligible to lay readers. Where they might not be able to judge the evidence, however, the readers would have clear impressions of the integrity and reliability of the debaters. The terms in which Jewel and his main opponent, Thomas Harding, addressed each other became a vital part of the argument. When Harding calls the Protestants 'Sacramentarians', Jewel would have the reader note 'by whiche Woorde he understandeth Schismatiques, Heretiques, and the enimies of God: and so breaketh up his way into this treatise with unsaverie, and bitter talke'. ${ }^{25}$ Even terming the other side 'adversary' is commented on adversely on both sides, though both sides used the term. ${ }^{26}$

Jewel's 'Challenge' caused a controversy that produced sixty-four texts by $1580 .^{27}$ As a means of defining the lines between Protestant Englishness and a foreign or traitorous Catholic opposition, it would be hard to equal. But it was not an unambiguous success, because the evidence became too hard for the intended audience to decipher and because many of the texts printed both sides of the argument and so gave rather too much space to the Catholic position. For this reason, the plan to place copies of Jewel's A Replie unto Hardinges Answer (1565) in every church in England came to nothing. ${ }^{28}$ Another book, perhaps a more successful instrument for confessionalization, was a required purchase for every parish in England: the second (1570) edition of John Foxe's Acts and monuments of these latter and perilous days ${ }^{29}$ was, by order of convocation, set up beside the Bible in cathedral churches; episcopal orders followed requiring parish churches to provide copies for readers. The Book of Martyrs required no skill in reading doctrinal disputes and offered a compelling narrative of truth repressed by the Catholic Church hierarchy. The work had 
many highly motivated and influential backers, like William Cecil, who supported Foxe and the printer John Day because of the important confessional function the work would serve. ${ }^{30}$ Elizabeth Evenden and Thomas Freeman have explained that the features that increased the size and cost of the volume - the inclusion of Latin documents, testimonies by multiple witnesses - were all elements that Foxe regarded as essential to establishing the veracity of his work. For the second edition, Catholic attacks (particularly from Nicolas Harpsfield's Dialogi Sex) were answered, the book's chronological range (making Foxe's view of Church history more prominent) was made longer, and additional documentation was added. ${ }^{31}$ This wealth of detail made Acts and Monuments effective for reassuring Protestants and created a text that Catholics found hard to answer convincingly. Evenden and Freeman write:

This detail gave the English Protestants an enormous polemic edge over their English Catholic opponents. To undermine Foxe's interpretation of the history of the English Church, Catholics had to be able to refute his massive documentation in detail. ... The Catholics had the scholarship but they did not have access to the manuscripts necessary to refute Foxe and these antiquarian works. Standing on a mountain of manuscripts, Foxe could plausibly claim that he could see more clearly into the hidden vales of the English past than his opponents could. ${ }^{32}$

The 'Challenge' sermon and Foxe's Acts and Monuments developed an argument about Church history that enabled Protestants to claim greater doctrinal affinity to the apostolic tradition than the mere institutional continuity about which the Catholic Church boasted; both texts provided an effective answer to the question 'where was your Church before Luther?'. Such weighty polemics were by no means the only texts that helped to define the lines of doctrinal and polemical demarcation between Protestants and Catholics at the time. The 
literature of conversion, particularly in 'motives tracts' written by clerical converts, also defined religious identities even as they describe movement between them. Here the understanding of conversion as a sudden change of heart and mind takes centre place, but it serves confessional purposes. Michael Questier's study of these texts demonstrates that clerical converts narrate their experience within the doctrinal framework appropriate to their new affiliation. Converts to Catholicism describe their experience as an enlightening of the mind about the nature of the true Church. Converts to Protestantism expressed their conversion in terms of sola fide justification. Grace enlightened the understanding and, realising that only faith in Christ could save, the sinner rejected Catholic teaching on the meritorious nature of good works. ${ }^{33}$

This 'script' served polemical purposes, supporting the doctrinal claims of the Church the convert had joined. The motives tract that we read are not transparent registers of a conversion experience: they were written according to a very well-known script and were shaped by a confessional imperative: to show that only one Church provided a safe haven for those whom God's grace had justified. We see this pattern in the recantation sermon of Theophilus Higgons (1578?-1659), a Church of England minister who had converted to Roman Catholicism some time in 1609 , but who reconverted to Protestantism and delivered a (very well-attended) recantation sermon at Paul's Cross on March 3rd, 1611. ${ }^{34}$ Higgons preached on Ephesians 2. 4-7 ('But God who is rich in mercy, through his great love, wherewith he loved us, Even when we were dead by sins, hath quickened us together in Christ, by whose grace you are saved', etc.), a strong proof-text for the Protestant doctrine of salvation. In his recantation, Higgons applies this doctrine to himself: his conversion to Catholicism was a fall from truth occasioned by his sins. Higgons insists that ordinary moral failings in himself (levity in deportment and 'prodigall apparell') ${ }^{35}$, and not any intellectual 
superiority in the opposition, lay behind his apostasy. The mercy of God prompted the repentance that brought him back into the fold of the Church of England.

Motives tracts by definition mark a 'turning' or change, and so perhaps it is not surprising that they represent clear lines of demarcation between religious confessions: for Higgons, Catholicism was a mistake brought on by a sinful nature. His reconciliation with the Church of England was a necessary corollary of his conversion to God. The cultural work being done by these texts is political, reinforcing the lines along which religious identities could be assessed in terms of civil and political conformity. Where conversion is not fully 'scripted' in a motives tract, the variousness of the experience of change of religion can be discerned. But it also becomes apparent how far modern critics are also wedded to that traditional script.

John Donne, for example, did not write a motives tract, but his account of his change of religion in the preface to Pseudo-martyr has been treated as a substitute. Donne does not narrate a 'road to Damascus' moment; he made no 'violent and sudden determination, till I had, to the measure of my poor wit and judgment, surveyed and digested the whole body of Divinity, controverted between ours and the Roman Church'. ${ }^{36}$ Donne does not elaborate on a process of spiritual enlightenment, nor does he name particular doctrines that crystallised his sense of a need to change religious affiliation. We import the conventions of the "motives tracts' to Pseudo-Martyr when we expect these things, and Pseudo-Martyr was designed for a different purpose: to suggest a separation between the obligations of political obedience and religious beliefs in order to convince Catholics to take the Oath of Allegiance.

Although no contemporary comments doubting the sincerity of Donne's conversion have survived, many modern scholars have assumed that it was only partial, or even a deliberate act of bad faith, an apostasy. Jeffrey Johnson outlines the debate between those who see Donne as continuing to be in some sense 'catholic' (perhaps lowercase catholic), and 
those who see him as some, but not very evident, kind of Protestant. ${ }^{37}$ More recently, Molly Murray looks at Donne's writings on conversion as evidence of crisis of definition: ‘inevitable misdesignation'. Although she premises her argument by stating that she takes Donne at his word (that he was born a Catholic and converted permanently to the Protestantism), she suggests that a reading of his poems shows that the resolution to remain Protestant 'did not preclude an ongoing interest in confessional change', and a sense that attempts to 'de-nominate' Christian belief existed in tension with Donne's belief that the sincere search for truth might make the convert on either side as good a Christian as the complacent believer who never doubted. ${ }^{38}$ Donne evidently had little time for those who 'say a Philip, or a Gregory, / A Harry, or a Martin, taught thee this'. ${ }^{39}$ Murray’s work demonstrates that literary texts by converts often renders ambiguous or problematic those distinctions in doctrine between Christian denominations that motives tracts seek to render clear and unambiguous. Her study reminds us that those tracts are rhetorically conditioned, and we must look elsewhere, perhaps primarily to poetry, for a corrective to their careful scripting of religious experiences in stories of conversions.

Change of religion across the chasm between Protestant and Catholics is a conversion narrative with which we are familiar. But what of those enthusiastic converts who found Elizabeth's church insufficiently Protestant: how did the Church cope with conversion to too hot a sort of Protestantism? Patrick Collinson has written that 'religion in the form of dissent, which was no less confessional, divided states, in France and Scotland to the extent of civil war. In those conditions religion was dysfunctional for the purposes of state formation' ${ }^{40}$ England was a confessional state insofar as it had an established church, but it fits the model of co-operation between Church and state rather badly in that an oppositional movement, aiming at further reformation, formed within the Church at the same time that the government was attempting to establish uniform Protestant worship. The difficulty in defining puritanism 
(as a movement or an evangelical trend within English Protestantism) has been fully argued by historians, and yet 'the puritan' appears to have been as recognisable for contemporary as it is for modern readers of early modern plays. ${ }^{41}$ The puritans were practitioners of 'voluntary religion': they created a more demanding religious regime for themselves and their households than that required by Church or state, and their criticism of the state-controlled Church was always threatening to lead to separation. They were conscientious, perhaps overscrupulous Protestants, and that made them problematic subjects in ways not dissimilar to Roman Catholic recusants. The story of how a radical element of the puritan movement sustained itself after the Star Chamber trials of 1591, to re-emerge demanding 'root and branch' changes to the Church's government in 1640 has been the study of extensive and impressive research by David Como and by Polly Ha: ${ }^{42}$ the puritan movement was never fully separate, but neither was it ever fully disconnected from the established church, and the web of relations (personal and doctrinal) between the pre-war movement and post-war Dissent are still being untangled. ${ }^{43}$

What of those whose allegiance to the Church was unquestioned? Was their religion less 'voluntary' than the Roman Catholic recusants, or converts, or puritan agitators? Many in England in the 1570s might best be described as 'Protestant-identifying': according to their puritan neighbours, their Protestantism was more about political loyalty and obedience than evangelical fervour. Being Protestant meant not being a papist; popery was the treasonous anti-religion against which Englishness and Protestantism could be defined, in Peter Lake's influential formulation. ${ }^{44}$ The activities of zealous preachers did not eliminate the "civil honest men' whose commitment to religion never got in the way of business or leisure. ${ }^{45}$ But we should not assume from the fulminations of puritan pastors that conformity to the established church remained merely a matter of political obedience for the majority of English people. (We are perhaps too apt to forget that for most people at the time, political 
obedience was a virtue not divorced from religion.) The changes of religion brought by the Elizabethan settlement became part of the fabric of domestic and community life, and however the process began (with perhaps little more than a failure to resist), it was not one in which laypeople were thoroughly passive. Andrew Pettegree writes:

In recent years historians have begun to call attention to the interpretative paradox we have been offered in recent studies of the English Reformation, a narrative in which English people deeply loved the practices of the old church, resented its disruption and accepted the new rites with passive incomprehension. And yet within two or three generations they cared sufficiently about their new church to want to defend it, doggedly and passionately, against two generations of the Stuart monarchy. By the seventeenth century, for all that they might not understand precise points of doctrine, many people held their new church in great affection, and felt an equal and profound dislike of Catholicism. ${ }^{46}$

The commitment of English people to the Elizabethan church grew over time, and not only because of state coercion, but because people decided to make it a part of the ordinary rounds of daily life. We have seen the Foxe's Acts and Monuments was a successful polemical text, but we know that it was also read in non-polemical ways. It was one of the books around which people built religious practices, and was read during household prayers, as a kind of alternative to the Bible. Women were encouraged to read it in private, as an act of devotion. Sometimes particular extracts, including letters of comfort from husbands to wives included by Foxe, were recommended or copied by readers. ${ }^{47}$ Abridged versions were sold: Clement Cotton's popular 1613 Mirror of Martyrs contained the most memorable speeches and prayers from Foxe's work but was shorn of theological controversy. Sold in duodecimo, it 
was a book designed for private or domestic devotion. ${ }^{48}$ Uses of devotional literature were not always determined by denominational differences, but the religious cultures of Europe's people were becoming more differentiated along confessional lines in the later sixteenth and seventeenth centuries. ${ }^{49}$ Judith Maltby in particular has demonstrated the growth of a positive and sincere commitment to the Book of Common Prayer through the late Elizabethan and early Stuart period. ${ }^{50}$ To borrow the title of Alec Ryrie's recent book, there is a concern among scholars to examine what 'being Protestant' meant, and not simply in the dichotomising sense of 'not being a papist'.

The lived experience of religion is not a detail: it is what that religion actually means to those who profess it. Protestantism was a religious force of astonishing power, which reshaped early modern Britain and through it, much of the modern world. But no religious movement, not even Reformed Protestantism, is a disembodied set of doctrines. It consists of people who have found a way of building their daily lives around it, and it is in those lives that it finds its meaning. ${ }^{51}$

The Reformation was not 'imposed by the authorities, clerical and lay, on largely passive, or even sullen and resentful parishioners', according to Andrew Pettegree; rather there was 'a process of continuous and gradual religious renewal in which many parishioners were active and willing participants, ${ }^{52}$ By this definition, 'being Protestant' was a more active force than we have assumed, and was not restricted to the self-defining enthusiasts of the puritan movement. This research is a clear development from earlier debates about the relationship between Protestantism and 'popular' culture, which became mired in the difficulties of defining a 'popular culture' as if it were hermetically sealed from 'learned' or 'elite' culture. ${ }^{53}$ By examining material culture and material texts, scholars have reached a more 
nuanced sense of the ways that changes in doctrine and liturgical practice were adapted and used to inform domestic arrangements and personal piety.

Such a gradual accommodation leaves us a long way from the sudden 'road to Damascus' model of conversion, and from the 'top down' understanding of a state-enforced religious conformity. Research on the Reformation is rediscovering the agency exercised by lay men and women in shaping the religious culture that informed their lives.

Confessionalization was a political process that the secular authorities could not entirely control. The English government grabbed the tiger's tale in the 1530 s and from then on had to adapt their political strategies to accommodate confessional politics. They could persuade and they could regulate and persecute; but whatever else, they had to give consideration to the religious choices of their people. People learned to identify with a particular religious denomination by an act of political obedience (or disobedience), or by a 'turn of heart', or by a combination of both, and they might move from one to another more than once in a lifetime. The absolute number of converts never mattered so much as the possibility of 'change of religion' that each convert represented to a government aiming for religious uniformity. By analysing the processes of conversion and confessionalization, scholars working on the political culture of the Reformation and the devotional culture of Protestantism, puritanism and Catholicism are mapping out a better understanding of the emergence of modern ideas of personal identity during the early modern period.

\section{Bibliography}

Coffey John, and Paul C. H. Lim, eds, The Cambridge Companion to Puritanism (Cambridge: Cambridge University Press, 2008). 
Evenden, Elizabeth and Thomas S. Freeman, Religion and the Book in Early Modern England: The Making of John Foxe's 'Book of Martyrs' (Cambridge: Cambridge University Press, 2011).

Lotz-Heumann, Ute, 'The Concept of "Confessionalization”: a Historiographical Paradigm in Dispute', Memoria y Civilización 4 (2001): 93-114.

Marshall, Peter, Religious Identities in Henry VIII's England (Aldershot: Ashgate, 2006). Murray, Molly, The Poetics of Conversion in Early Modern English Literature: Verse and Change from Donne to Dryden (Cambridge: Cambridge University Press, 2009).

Pettegree, Andrew, Reformation and the Culture of Persuasion (Cambridge: Cambridge University Press, 2005).

Questier, Michael, Conversion, Politics and Religion in England, 1580-1625 (Cambridge: Cambridge University Press, 1996).

Ryrie, Alec, Being Protestant in Reformation England (Oxford: Oxford University Press, 2013).

Simpson, James, Burning to Read: English Fundamentalism and its Reformation Opponents (Cambridge MA: Belknap Press, 2007).

\footnotetext{
1 'Confessionalism, n.' OED Online. Oxford University Press, June 2014. Web. 21 July 2014.

2 Christopher Haigh, English Reformations: Religion, Politics and Society under the Tudors (Oxford: Oxford University Press, 1993). Along with Eamon Duffy's The Stripping of the Altars: Traditional Religion in England, 1400-1580 (New Haven: Yale University Press, 1992), Haigh's work caused a thorough reassessment of the popularity of Protestantism before 1570. For a summary of the revisionist debate on the progress of the English Reformation, see Ethan Shagan, 'Introduction: English Catholic History in Context', in Catholics and the 'Protestant Nation': Religious Politics and Identity in Early Modern
} 
England, edited by Ethan H. Shagan (Manchester: Manchester University Press, 2005), 1-21, esp. 1-6. For an assessment of the strengths and weaknesses of the 'revisionist' case, see Nicholas Tyacke, 'Re-thinking the "English Reformation”, in Aspects of English Protestantism, c.1530-1700 (Manchester: Manchester University Press, 2001), 37-60.

${ }^{3}$ A good account of this can be found in Molly Murray, 'Conversion and Poetry in Early Modern England', in A New Companion to English Renaissance Literature and Culture, edited by Michael Hattaway (Oxford: Blackwells, 2010), II: 407-422.

${ }^{4}$ One of the most sensitive readings of these texts is Patricia Crawford, The Puritan Conversion Narrative: The Beginnings of American Expression (Cambridge University Press, 1983). On English conversion narratives of the late seventeenth and eighteenth centuries, see D. Bruce Hindmarsh, The Evangelical Conversion Narrative: Spiritual Autobiography in Early Modern England (Oxford: Oxford University Press, 2007).

${ }^{5}$ Michael Questier, Conversion, Politics and Religion in England, 1580-1625 (Cambridge: Cambridge University Press, 1996), 58. For the different ways that the relationship between grace and human psychology and between grace and the Church was modelled in Protestant and Catholic traditions, see pp. 58-75.

${ }^{6}$ Alec Ryrie, 'Counting Sheep, Counting Shepherds: The Problem of Allegiance in the English Reformation', in The Beginnings of English Protestantism, edited by Peter Marshall and Alec Ryrie (Cambridge: Cambridge University Press, 2002), 84-110, 105.

${ }^{7}$ Ethan H. Shagan, Popular Politics and the English Reformation (Cambridge: Cambridge University Press, 2003), 31-60, esp. 51.

${ }^{8}$ The phrase is Diarmaid MacCulloch's: 'The Impact of the English Reformation', The Historical Journal 38 (1995): 151-153, esp. 152.

${ }^{9}$ Ute Lotz-Heumann, “The Concept of “Confessionalization”: a Historiographical Paradigm in Dispute', Memoria y Civilización 4 (2001): 93-114. 
${ }^{10}$ Tom Webster, 'Early Stuart Puritanism', in Cambridge Companion to Puritanism, edited by John Coffey and Paul C.H. Lim (Cambridge: Cambridge University Press, 2008), 48-66, esp. 61; Robert Herrick, 'The Argument of his Book', in Ben Jonson and the Cavalier Poets, ed. Hugh Maclean (New York: W.W. Norton, 1974), 104-105. On the 'Terling thesis' that increased social regulation of the poor is linked with puritanism in the 'middling sort', see Keith Wrightson 'Postscript: Terling Revisited', in Keith Wrightson and David Levine, Poverty and Piety in an English Village: Terling, 1525-1700, $2^{\text {nd }}$ ed. (Oxford: Oxford University Press, 1995), 197-220.

${ }^{11}$ Peter Marshall, '(Re) defining the English Reformation', Journal of British Studies 48 (2009): 564-586, esp. 575.

${ }^{12}$ Peter Marshall, Religious Identities in Henry VIII's England (Aldershot: Ashgate, 2006), 3.

${ }^{13}$ Lotz-Heumann, 'The Concept of "Confessionalization”, 109-114.

${ }^{14}$ Marshall, '(Re)defining the Reformation', 585-586.

${ }^{15}$ Diarmaid MacCulloch, Reformation: Europe's House Divided 1490-1700 (Oxford: Oxford University Press, 2003), 338.

${ }^{16}$ On the cultural and intellectual framework for enforcing conformity and orthodoxy, see John Coffey, Persecution and Toleration in Protestant England, 1558-1689 (London: Pearson, 2000), esp. 10-46. For a survey of scholarship on toleration and persecution, see Alexandra Walsham, Charitable Hatred: Tolerance and Intolerance in England, 1500-1700 (Manchester: Manchester University Press, 2006), 1-38.

${ }^{17}$ Questier, Conversion, Politics and Religion, 3, 201.

${ }^{18}$ Andrew Pettegree, 'Printing and the Reformation: the English Exception', in The Beginnings of English Protestantism, edited by Peter Marshall and Alec Ryrie (Cambridge: Cambridge University Press, 2002), 157-179. In Reformation and the Culture of Persuasion, Pettegree points out that print media worked best in conjunction with others. The 
Reformation could survive 'by print alone', but it did not always 'thrive': Reformation and the Culture of Persuasion (Cambridge: Cambridge University Press, 2005), 170-179.

${ }^{19}$ Andrew Pettegree, Reformation and the Culture of Persuasion, 8.

${ }^{20}$ Peter Lake and Steve Pincus, 'Rethinking the Public Sphere in Early Modern England', in The Politics of the Public Sphere in Early Modern England, edited by Peter Lake and Steven Pincus (Machester: Manchester University Press, 2007), 1-30 .

${ }^{21}$ Torrance Kirby, Persuasion and Conversion: Essays on Religion, Politics, and the Public Sphere in Early Modern England (Leiden: Brill, 2013), esp. 1-8.

${ }^{22}$ James Simpson, Burning to Read: English Fundamentalism and its Reformation Opponents (Cambridge MA: Belknap Press, 2007), 45.

${ }^{23}$ See my Politics and the Paul's Cross Sermons, 1558-1642 (Oxford: Oxford University Press, 2011), 164-166.

${ }^{24}$ John Jewel, 'The Copie of a Sermon Pronounced by the Byshop of Salisburie at Paules Crosse', part 2 of The True Copies of the Letters betwene the Reverend Father in God John Bisshop of Sarum and D. Cole (London, [1560]).

${ }^{25}$ A Replie unto M. Hardinges Answeare (1565), 379. See also p. 496 ('new maisters'), p. 413 ('new doctor), and p. 629 ('Genevians')

${ }^{26}$ Thomas Harding refers to the Protestants as 'our adversaries' in An Answere to Maister Juelles Chalenge (Louvain, 1564), f. 165r and 167v, 169v, 173v, 181v, even though in the preface to Jewel he complains of Jewel using this term of Catholics. Jewel responded that this was a 'civile, and courteous a name' for those who met Protestants 'armed with Swearde, and Fiere, and embrewed with out bloude': Replie, sig. I[4r.

${ }^{27}$ A. C. Southern, English Recusant Prose, 1559-1582 (London: Sands, 1950), 60-66.

${ }^{28}$ Southern, English Recusant Prose, 43-44. 
${ }^{29}$ David Loades, 'The Early Reception', in The Unabridged Acts and Monuments Online or TAMO (HRI Online Publications, Sheffield, 2011). (HRI Online Publications, Sheffield, 2011). Available from: http//www.johnfoxe.org [Accessed: 17.04.2014].

${ }^{30}$ Elizabeth Evenden and Thomas S. Freeman, Religion and the Book in Early Modern England: The Making of John Foxe's 'Book of Martyrs' (Cambridge: Cambridge University Press, 2011), 102-8. On the help that Foxe received from other contributors (those who witnessed events or who supplied documents to Foxe), see John King, Foxe's Book of Martyrs and Early Modern Print Culture (Cambridge: Cambridge University Press, 2006), $25-37$.

${ }^{31}$ Evenden and Freeman, Religion and the Book in Early Modern England, 124-126, $132-$ 133, 139-149, 173-183. See also King, Foxe's Book of Martyrs and Early Modern Print Culture, 113-23.

${ }^{32}$ Evenden and Freeman, Religion and the Book in Early Modern England, 158.

${ }^{33}$ Questier, Conversion, Politics and Religion, 58-70.

${ }^{34}$ Theophilus Higgons, A Sermon preached at Pauls Crosse the third of March, 1610 (1611). Higgons' 'motives tract' for his conversion to Catholicism is The First Motive of T.H. Maister of Arts and lately Minister, to Suspect the Integrity of his Religion ... ([Douai], 1609), which was answered by Sir Edward Hoby and to which Higgons responded with The Apology of T. Higgons lately a Minister now Catholique (Roan, 1609).

${ }^{35}$ Higgons, A Sermon preached at Pauls Crosse, 43.

${ }^{36}$ John Donne, Pseudo-Martyr, edited by Anthony Raspa (Montreal: McGill University Press, 1993), 13.

${ }^{37}$ Jeffrey Johnson, The Theology of John Donne (Cambridge: D S Brewer, 1999), 38-9.

${ }^{38}$ Molly Murray, The Poetics of Conversion in Early Modern English Literature: Verse and Change from Donne to Dryden (Cambridge: Cambridge University Press, 2009), 69-104. 
39 'Satyre III', 11. 96-7 The Complete Poems of John Donne, ed. Robin Robbins (Harlow: Longmans Annotated English Poets, 2008), 396.

${ }^{40}$ Patrick Collinson, 'Religion and Politics in Elizabethan England', Historical Research 82 (2009): 74-92, esp. 76.

${ }^{41}$ John Coffey and Paul C. H. Lim, 'Introduction', in The Cambridge Companion to Puritanism; Peter Lake, 'The Historiography of Puritanism', in Cambridge Companion to Puritanism, 346-371. Patrick Collinson, 'Ecclesiastical Vitriol: Religious Satire in the 1590s and the Invention of Puritanism', in The Reign of Elizabeth I: Court and Culture in the Last Decade, edited by John Guy (Cambridge: Cambridge University Press, 1995), 150-170; Christopher Haigh, 'The Character of an Antipuritan', Sixteenth Century Journal 35 (2004): $671-688$.

${ }^{42}$ David Como, Blown by the Spirit: Puritanism and the Emergence of an Antinomian Underground in Pre-Civil-War England (Stanford University Press, 2004); Polly Ha, English Presbyterianism, 1590-1640 (Stanford, CA: Stanford University Press, 2011).

${ }^{43}$ John Spurr, 'Late Stuart Puritanism', in The Cambridge Companion to Puritanism, 89-105; Spurr, English Puritanism, 1603-1689 (Basingstoke: Macmillan, 1998); Neil H. Keeble, The Literary Culture of Nonconformity in Late Seventeenth-century England (Leicester: Leicester University Press, 1987).

${ }^{44}$ Peter Lake 'Anti-popery: The Structure of a Prejudice', in Conflict in Early Stuart England: Studies in Religion and Politics, 1603-1642 edited by Richard Cust and Ann Hughes (London: Longmans, 1989), 72-106.

${ }^{45}$ Christopher Haigh has argued that the expectations of committed Protestants and puritans far exceeded those of many English people who nonetheless considered themselves good Christians: The Plain Man's Pathways to Heaven: Kinds of Christianity in Post-Reformation England, 1570-1640 (Oxford: Oxford University Press, 2007), 59-97. 
${ }^{46}$ Pettegree, Reformation and the Culture of Persuasion, 75.

${ }^{47}$ King, Foxe's Book of Martyrs and Early Modern Print Culture, 288-303. Grace Mildmay bequethed a copy, along with a Bible and a copy of The Imitation of Christ to her daughter: Tara Hamling, 'Old Robert's Girdle; Visual and Material Props for Protestant Piety in postReformation England', in Private and Domestic Devotion in Early Modern Britain, edited by Jessica Martin and Alec Ryrie (Aldershot: Ashgate, 2012), 135-163, esp. 156.

${ }^{48}$ King, Foxe's Book of Martyrs and Early Modern Print Culture, 139-144. On other abridged versions, see pp. 153-57.

${ }^{49}$ The most obvious example of a devotional text that crossed denomination barriers is Robert Parson's Christian Directory. See John R. Yamamoto-Wilson, ‘Robert Person's Resolution (1582) and the Issue of Textual Piracy in Protestant Editions of Catholic Devotional Material', Reformation and Renaissance Review 15 (2013): 177-98. Despite its easy adaptation to Protestant use, it was reported to be one of the most successful texts for creating converts to Rome: See Questier, Conversion, Politics and Religion in England, 3739, 84-86. On Protestantism as 'devotionally omnivorous' and ready to adapt material from other traditions, see Alec Ryrie, Being Protestant in Reformation England (Oxford: Oxford University Press, 2013), 286-287.

${ }^{50}$ Judith Maltby, Prayer Book and People in Elizabethan and Early Stuart England (Cambridge: Cambridge University Press, 1998). On the integration of Protestant piety into domestic settings, see Tara Hamling, 'Living with the Bible in Post-Reformation England: The Materiality of Text, Image and Object in Domestic Life', in Studies in Church History: Religion and the Household, edited by John Doran, Charlotte Methuen and Alexandra Walsham (Suffolk: Boydell Press, 2014), 210-239. Margo Todd's magisterial study of PostReformation Scotland demonstrates the thoroughness with which religious ideas can be 
incorporated into quotidian community life: The Culture of Protestantism in Early Modern Scotland (New Haven: Yale University Press, 2002).

${ }^{51}$ Ryrie, Being Protestant in Reformation England, 2.

${ }^{52}$ Pettegree, Reformation and the Culture of Persuasion, 187.

${ }^{53}$ Trevor Johnson, 'The Reformation and Popular Culture', in The Reformation World, edited by Andrew Pettegree (London: Routledge. 2000), 545-560. Alexandra Walsham's exhaustive study of popular ideas of providence is in many ways a study of an idea particularly associated with Protestantism could become an important element in popular culture, particularly in response to 'popular Pelagianism', the persistent habit of laypeople of thinking that God would not damn those who did their best: Walsham, Aspects of Providentialism in Early Modern England (Cambridge: Cambridge University Press, 1994). 